\title{
MANAJEMEN PEMBELAJARAN TAHFIZ AL-QUR'AN DALAM MENCAPAI TARGET HAFALAN DI SMP ISLAM DARUL MUTTAQIN METRO LAMPUNG
}

\author{
Bambang Rudianto', M. Ihsan Dacholfany ${ }^{2 *}$, Sudirman Aminin ${ }^{3}$ \\ 1,2*3 Universitas Muhammadiyah Metro, Lampung, Indonesia
}

E-mail: $\quad$ bambangrudianto002@gmail.com ${ }^{1)}$

\begin{abstract}
Abstrak
Dasar pendidikan dalam Islam adalah Qur'an dan Hadist karena keduanya merupakan sumber dan dasar untuk menjalani kehidupan di dunia ini. Oleh karena itu orang menginginkan anaknya sholeh dengan cara menghafal Al-Qur'an. Sedangkan penelitian ini bertujuan mengetahui seberapa jauh manajemen pembelajaran tahfidz Al-Qur'an dalam mencapai target hafalan di SMP Islam Darul Muttaqin Metro Lampung.

Pendekatan yang digunakan adalah pendekatan kualitatif yang menitikberatkan pada data kualitatif, yaitu data wawancara, observasi dan dokumentasi. Pengumpulan datanya menggunakan instrumen penelitian berupa daftar pertanyaan yang terangkum dalam pedoman wawancara. Pedoman wawancara menggunakan triangulasi yang ditujukan kepada kepala sekolah, guru/ustadz, siswa/santri, dan komite. Analisa data yang digunakan dalam penelitian ini meliputi: pengumpulan data, reduksi data, penyajian data dan penarikan kesimpulan.

Hasil penelitiannya: (1) Perencanaan pembelajaran tahfidz Al-Qur'an berjalan dengan baik, terutama dalam mengatur, mengelola, dan mengarahkan rencananya. (2) Pelaksanaan pembelajaran tahfidz Al-Qur'an berjalan, terorganisasi, dan dimanaj dengan baik, walaupun dalam wabah/pandemic coronavirus (covid-19) dan diberlakukannya sistem lockdown. (3) Program pembelajaran tahfidz al-Qur'an SMP Islam Darul Muttaqin Metro termasuk program kurikulum khas/unggulan. Kurikulum ini dikembangkan secara mandiri yang membedakan dengan sekolah lain. (4) Evaluasi pembelajaran tahfidz Al-Qur'an dari metode menghafal, ustadz/guru, teknik bimbingan dalam menyetor, materi tahfidz, sarana prasarana, dan reward/panisment terlaksana dengan baik juga. (5) Kendalanya dari faktor pendukung, yaitu kecerdasan siswa, usia siswa, minat siswa yang tinggi, perhatian guru, motivasi orang tua yang sangat kuat, dan fasititas yang memadai. Sedangkan dari faktor penghambat, yaitu malas, tidak sabar, putus asa, tidak bisa mengatur waktu, sering lupa, dan munculnya wabah coronavirus (covid-19). (6) Solusinya, yaitu meninggalkan kemalasannya, pandai mengatur waktu, harus sering dimurajaah, dan pembelajaran lewat daring (viarekaman).

Dari analisis tersebut dapat disimpulkan bahwa manajemen pembelajaran tahfidz Al-Qur'an berjalan baik, kondusif, efektif, dan solutif.
\end{abstract}

Kata Kunci : Manajemen Pembelajaran Tahfidz Al-Qur’an dan Target Hafalan

\begin{abstract}
The basis of education in Islam is the Qur'an and the Hadith because both are sources and basis for living life in this world. Therefore people want their children to be pious by memorizing the Qur'an. While this study aims to find out how far the management of tahfidz Al-Qur'an learning is in achieving rote targets at the Darul Muttaqin Islamic Middle School in Metro Lampung.

The approach used is a qualitative approach that focuses on qualitative data, namely interview data, observation and documentation. The data collection uses a research instrument in the form of a list of questions summarized in the interview guidelines. The interview guide uses triangulation aimed at school principals, teachers / teachers, students / students, and committees. Analysis of the data used in this study include: data collection, data reduction, data presentation and drawing conclusions.

The results of his research: (1) The planning of learning the Koran tahfidz goes well, especially in organizing, managing, and directing its plans. (2) The implementation of tahfidz Al-Qur'an learning runs well organized and managed, even in the pandemic coronavirus (covid-19) and the lockdown system. (3) The Tahfidz al-Qur'an learning program at the Darul Muttaqin Metro Islamic Middle School includes a distinctive / excellent curriculum program. This curriculum is developed independently which distinguishes
\end{abstract}


it from other schools. (4) Evaluation of Al-Qur'an's learning tahfidz from memorization methods, chaplain Iteacher, deposit guidance techniques, tahfidz material, infrastructure, and reward / panisment are carried out well too. (5) The constraints of supporting factors, namely student intelligence, student age, high student interest, teacher attention, very strong parent motivation, and adequate facilities. While the inhibiting factors, namely lazy, impatient, hopeless, unable to manage time, often forget, and the emergence of coronavirus outbreaks (covid-19). (6) The solution, which is to abandon laziness, be good at managing time, must often be educated, and online learning (via recording).

From this analysis it can be concluded that the management of tahfidzAl-Qur'an learning is going well, conducive, effective, and solutive.

Keywords: Learning Management Tahfidz Al-Qur'an and Target Memorization.

\section{PENDAHULUAN}

Dasar pendidikan dalam Islam berasal dari Qur'an dan Hadist karena keduanya merupakan sumber dan dasar untuk menjalani kehidupan di dunia ini. Islam juga merupakan satu-satunya agama yang mawajibkan setiap umatnya untuk selalu belajar.

Usia remaja adalah usia belajar dan saat anak mengalami banyak perubahan, baik secara fisik maupun mental. Mereka yang sebelum masa itu, taat kepada orang tua, mulai berani membantah. Begitu juga dengan kebiasaan mengaji, yang biasanya rajin mulai malas dan lebih senang untuk bermain. Perubahan ini sering membuat orang tua mengalami kesulitan dalam menghadapi anaknya.

SMP Islam Darul Muttaqin Metro adalah suatu lembaga/yayasan pendidikan formal yang terdapat di pondok pesantren Darul Muttaqin Kota Metro. SMP Islam Darul Muttaqin secara luas mengkaji Islam. Siswa/santri tidak hanya menghafal Al-Qur'an, tetapi juga mempelajari ilmu pengetahuan umum sesuai dengan tingkatnya.

Adapun tujuan penulis tertarik meneliti adalah untuk mengetahui seberapa jauh "Manajemen Pembelajaran Tahfidz Al-Qur'an Dalam Mencapai Target Hafalan di SMP Islam Darul Muttaqin Metro Lampung" yang telah dilakukan.

Menurut Husaini Usman, (2008) mendifinisikan mempunyai dua pengertian. Pertama, management dalam arti sempit adalah management sekolah/madrasah yang meliputi; perencanaan program sekolah/madrasah, pelaksanaan program sekolah/madrasah, kepemimpinan kepala sekolah / madrasah, pengawasan/evaluasi, dan sistem informasi sekolah/madrasah. Kedua, management dalam arti luas adalah perencanaan, pengorganisasian, pengendalian, dan penilaian ( $\mathrm{P} 4)$.

Howard M.Carlisle dalam Makbuloh (2011:39) mengatakan bahwa management adalah proses mengarahkan, mengoordinasikan, dan memengaruhi operasional organisasi untuk memeroleh hasil yang diinginkan, serta meningkatkan penampilan organisasi secara keseluruhan.

Berdasarkan masing-masing pengertian di atas dapat disimpulkan bahwa manajemen pembelajaran merupakan upaya untuk mengelola alam semesta (Al-Qauni), kehidupan (Al-Hayah), dan manusia (Al-Insan) yang mencakup perencanaan pembelajaran, pelaksanaan pembelajaran, dan evaluasi pembelajaran untuk meraih tujuan pembelajaran secara tepat, berdaya guna, bermutu, dan bermanfaat bagi umat manusia, sehingga menjadikan hidup yang rahmatan lil'alamin.

\section{METODE PENELITIAN}

Pada penelitian ini penulis akan menggunakan pendekatan kualitatif dengan metode deskriptif. Pendekatan ini sebagai tahapan penelitian yang menghasilkan data deskriftif berupa pernyataan tertulis atau lisan dari orang-orang dan prilaku yang diobservasi yang bertujuan menggambarkan suatu keadaan sifat seperti apa adanya. 
Kemudian Pendekatan kualitatif akan menyajikan data berupa pernyataan tertulis dan bukan rangkaian angka. Data tersebut akan didapatkan dengan berbagai cara antara lain observasi, wawancara, dokumentasi, dan rekaman. Selanjutnya, data akan diolah dengan cara mencatat, menulis, dan lain sebagainya.

\section{HASIL DAN PEMBAHASAN}

Pada pembahasan mengacu pada diskusi temuan penelitian, dilakukan dengan menyajikan analisis substantif teoritik yang mengacu kepada teori tentang Manajemen Pembelajaran Tahfidz Al-Qur'an Dalam Mencapai Target Hafalan Di SMP Islam Darul Muttaqin Metro Lampung. Makna yang disajikan didasarkan atas interpretasi data yang berupa pernyataan responden yang diformulasikan dalam bentuk temuan. Bogdan dan Biklen (1982) mengemukakan bahwa tema adalah konsep atau teori yang ditampilkan oleh data yang ditemukan dalam penelitian, oleh karena itu maka arah interpretasi dari diskusi temuan penelitian ini, dikerjakan dengan memperhatikan sifat penelitian, yaitu penelitian kualitatif induktif .

Dengan kesimpulan induktif yang bertolak dari kenyataan tentang Manajemen Pembelajaran Tahfidz Al-Qur'an Dalam Mencapai Target Hafalan Di SMP Islam Darul Muttaqin Metro Lampung, maka temuan teoritik dikumpulkan akan mengarah pada kesejajaran, dalam arti memperluas atau melengkapi atau bahkan ada kemungkinan menolak teori tentang Manajemen Pembelajaran Tahfidz Al-Qur'an Dalam Mencapai Target Hafalan yang sudah meningkat.

Temuan penelitian ini merupakan hasil yang diperoleh peneliti dari objek penelitian yang didasarkan pada fokus penelitian. Temuan penelitian dapat berasal dari data wawancara, observasi, dan dokumen-dokumen yang mendukung. Selanjutnya data dipilah sesuai dengan fokus penelitian yang meliputi: (1) deskripsi manajemen pembelajaran tahfidz al-qur'an, (2) deskripsi kendala dan solusi pembelajaran tahfidz al-qur'an.

\section{Hasil Deskripsi Manajemen Pembelajaran Tahfidz Al-Qur'an}

Pada hakikatnya manajemen pembelajaran tahfidz Al-Qur'an terdiri dari perencanaan, pelaksanaan, dan evaluasi pembelajaran. Berikut adalah hasil deskripsi manajemen pembelajaran tahfidz Al-Qur' an dalam mencapai target hafalan di SMP Islam Darul Muttaqin Metro Lampung.

\section{Perencanaan Pembelajaran Tahfidz Al-Qur'an}

Merencanakan bukanlah tugas yang ringan. Berbagai aspek seringkali menyebabkan munculnya kerumitan, baik itu aspek dalam (intern) terkait dengan masalah emosi, pikiran, perilaku dan aspek luar (ekstern) peserta didik yang terkait masalah suasana lingkungan belajar, penempatan peserta didik, jumlah siswa/santri, dan sebagainya. Perencanaan yang asal-asalan jelas tidak bisa menghasilkan proses pembelajaran yang efektif, melainkan secara nyata dapat menghasilkan proses pembelajaran yang kurang baik. Perencanaan dapat berjalan dengan baik manakala guru/ustadz mempunyai kepiawaian dalam mengatur dan mengarahkan perencanaan dalam kegiatan pembelajaran tahfidz Al-Qur'an.

Temuan lapangan tersebut berdasarkan interpretasi peneliti, adanya perencanaan yang terorganisasi dengan baik, walaupun dalam keadaan wabah coronavirus (covid-19). Dengan hasil temuaan lapangan seyogyanya mendapat dukungan penuh dari seluruh 
warga sekolah karena dengan perencanaan secara terrah dan terprogram baik akan berefek pada kesuksesan pembelajaran. Pembelajaran yang sukses tentu akan berdampak pada mutu pendidikan nasional. Mutu pendidikan dikatakan baik, berarti didukung adanya kualitas lulusan (output) yang bermutu.

Atas dasar uraian di atas selanjutnya dapat ditarik suatu simpulan bahwa perencanaan merupakan proses atau usaha yang dilakukan guru/ustadz secara sistematis untuk menciptakan dan mewujudkan perencanaan yang dinamis dan kondusif dalam rangka menciptakan pembelajaran yang efektif dan efisien. Perencanaan sebagai aspek yang harus diorganisasi dan dikelola secara baik agar kegiatan belajar mengajar (KBM) dapat terarah dan menuju pada sasaran yang dikehendaki.

\section{Pelaksanaan Pembelajaran Tahfidz Al-Qur'an}

Pelaksanaan kegiatan pembelajaran tahfidz Al-Qur'an adalah kelanjutan dari perencanaan pembelajaran tahfidz Al-Qur'an. Pelaksanaan ini bukanlah tugas yang ringan. Berbagai masalah seringkali muncul, baik dari dalam maupun dari luar. Terkait dengan masalah yang muncul dari dalam/luar adalah perubahan jadwal pembelajaran tahfidz Al-Qur'an yang semula perencanaanya sebagai berikut:

a) Dari Senin sampai dengan Sabtu dimulai ba'da subuh sampai dengan jam 06.00 WIB.

b) Senin sampai Kamis pukul 07.15 - 08.15 WIB.

c) Senin sampai Sabtu ba'da solat magrib sampai waktu solat isya'.

coronavirus (covid-19) telah mamaksa siswa/santri untuk belajar di rumah masingmasing melalui pembelajaran daring (via-rekaman).

Pada Temuan lapangan tersebut, adanya pelaksanaan yang terorganisasi dengan baik, walaupun dalam keadaan wabah coronavirus (covid-19) dan diberlakukannya sistem lockdown. Dengan hasil temuaan lapangan tentang pelaksanaan pembelajaran tahfidz Al-Qur'an yang terprogram dengan baik akan berefek pada tercapainya target hafalan. Pelaksanaan pembelajaran yang sukses tentu akan berdampak pada capaian target hafalan.

\section{Evaluasi Pembelajaran Tahfidz Al-Qur'an}

Akhir kegiatan pelaksanaan pembelajaran tahfidz Al-Qur'an adalah evaluasi pembelajaran. Tentunya yang akan dibahas adalah metode menghafal, ustadz/guru, teknik bimbingan dalam menyetor, materi tahfidz, sarana prasarana, dan reward atau panisment.

\section{Metode Menghafal}

Pada dasarnya metode menghafal diserahkan kepada kreativitas dan kencendrungan masing-masing santri/siswa, tetapi kebanyakan siswa/santri memakai metode tilawah dan metode wahdah dalam pembelajaran tahfidz Al-Qur'an lebih mudah dan dipahami oleh santri/siswa. Akan tetapi dengan adanya wabah coronavirus (covid19) tidak ada jalan lain kecuali dengan menggunakan metode Via-Rekaman.

\section{Ustadz/guru Pembimbing}

Ustadz/guru sebagai salah satu bagian di dalam aktivitas belajar mengajar, mempunyai posisi sangat menentukan dalam keberhasilan pembelajaran, sebab fungsi utama guru/ustadz adalah merancang, mengelola, melaksanakan, mengevaluasi, serta menindaklanjuti perbaikan pembelajaran tahfidz Al-Qur'an. Ketika perencanaan kurang 
bisa dipakai dengan adanya wabah coronavirus (covid-19), maka ustadz/guru SMP Islam Darul Muttaqin Metro Lampung telah mengelola dengan pembelajaran sistem daring.

\title{
1) Teknik Bimbingan dalam Menyetor
}

Dalam kegiatan pembelajaran tahfidz Al-Qur'an untuk dapat mencapai target hafalan tentunya ada beberapa teknik bimbingan dalam menyetor hafala tersebut guna membantu mempermudah membentuk stimulus dalam ingatan terhadap ayat-ayat yang dihafal, maka diperlukan teknik bimbingan dalam menyetor hafalan yang baik, karena teknik bimbingan dalam menyetor hafalan akan mempengaruhi keberhasilan dalam menghafal Al- Qur'an. Teknik bimbingan dalam menyetor hafalan tentunya setiap anak agak berbeda tergantung siswa/santri mana yang dianggap lebih mudah untuk siswa/santri tersebut.

Dari dua pernyataan tersebut dapat dihipotesiskan bahwa: teknik bimbingan dalam menyetor hafalan selama ini sebelum ada wabah coronavirus (covid-19) dengan cara tatap muka antara ustadz/guru dengan santri/siswa tetapi dengan adanya wabah coronavirus (covid-19) pembelajaran tahfidz Al-Qur'an dengan cara via-rekaman.

\section{2) Materi Tahfidz}

Materi pembelajaran tahfidz diawali dengan menghafal juz tigapuluh (30) dimulai dari surat An-Naas sampai dengan surat An-Naba'. Baru sesudah juz Amma' hafal semua dengan baik, maka dapat dimulai lagi dengan surat-surat pilihan, seperti surat AlKahfi, Yasin, As Sofat, Al-Mulk, Al-Waqiah, Ar-Rahman, dan seterusnya. Atau bisa memulai dari juz 1 atau juz 29.

\section{3) Sarana Prasarana}

Sarana prasarana atau alat dan sumber pembelajaran yang digunakan dalam pembelajaran tahfidz al-qur'an diantarnya ialah alat multimedia seperti: (a) komputer/laptop beserta infocus; (b) television dan VCD Player; (c) Tape dan flasdisk atau CD; (d) Proyektor atau OHP, (e) Hand phone dan sebagainya. Tetapi untuk saat sekarang ini dengan munculnya wabah coronavirus (covid-19) yang paling tepat adalah Android.

\section{4) Reward/Panisment}

Untuk memberikan apresiasi dan penghargaan kepada siswa/santri yang sudah menyelesaikan target hafalan selama pendidikan di SMP Islam Darul Muttaqin Metro Lampung dan lulus dalam ujian, maka bagi yang lulus 1 juz izin pulang 3 hari. Dibuatlah Ifadah, Syahadah, dan ijazah tahfidz santri yang lulus ujian tahidz 15 juz, 30 juz, dan mendapatkan sanad, maka diwisuda secara khusus dalam wisuda tahfidz qur'an. Juga santri yang benar-benar hafal 30 juz akan menjadi duta dalam perwakilan sekolah tahfidz qur'an SMP Islam Darul Muttaqin Metro Lampung dalam acara-acara murajaah bersama dengan sekolah/pondok pesantren tahfidz qur'an lainnya.

\section{Hasil Deskripsi Kendala dan Solusi Pembelajaran Tahfidz Al-Qur'an}

\author{
a. Aspek pendukung Pembelajaran Tahfidz Al-Qur'an
}


Adapun aspek pendukung dalam pembelajaran tahfidz Al-Qur'an diantaranya :

1) Siswa/santri itu sendiri.

2) Orang tua/wali siswa/santri

3) Guru/ustadz dan

4) Lingkungan sekitarnya.

\section{b. Aspek Penghambat dalam Pembelajaran Tahfidz Al-Qur'an}

Ada beberapa hambatan di dalam menghafal al-Qur'an di SMP Islam Darul Muttaqin Metro Lampung diantaranya :

1) Guru/ustadz pasif/monoton dalam pembelajaran tahfidz atau kurang kreatif dan kurang tegas kepada siswa/santri yang tidak semangat dalam menghafalkan Al-Qur'an,

2) Ada beberapa siswa/santri yang belum bisa membaca al-qur'an,

3) Lingkungan belajar sekolah yang kurang baik.

\section{c. Problematika Pembelajaran Tahfidz dan Solusinya}

Problematika pembelajaran tahfidz khususnya dalam menghafal Al Qur'an sering dialami oleh siswa/santri diantaranya harus melewati sebuah ujian dan cobaan. Problematika yang sering dialami adalah berat hati, kurang sabar dan apatis, sulit mengelola waktu, dan sering terselap/lupa.

Selain problematika yang dialami siswa/santri di atas, ada beberapa problematika/kendala/masalah yang mungkin tidak ada sebelumnya, yaitu munculnya wabah Coronavirus (covid-19). Virus ini adalah virus baru penyebab penyakit saluran pernafasan yang berasal dari Wuhan China. Coronavirus ini merupakan family dari virus Sars dan Mers. Maka dari coronavirus (covid-19) muncul kendala-kendala yang mengakibatkan dampak yang luar biasa, yang melumpuhkan di segala aspek kehidupan, terutama di bidang pendidikan.

\section{1) Sekolah diliburkan}

Berikut ini adalah kendala/dampak dan solusi dari coronavirus (covid-19) :

Sejak munculnya wabah coronavirus (covid-19) atau pandemi covid-19, maka sekolah-sekolah atau seluruh aktivitas yang melibatkan khalayak banyak diliburkan, sehingga pemerintah mengambil kebijakan untuk belajar di rumah atau homeschooling.

\section{2) Setoran hafalan lewat via-rekaman}

Untuk mengisi kegiatan pembelajaran tahfidz Al-Qur'an di tengah wabah coronavirus (covid-19) maka dilakukan pembelajaran dengan via-rekaman, yaitu santri/siswa menghafal, direkam, dan kemudian dikirim ke ustadz/guru. Kemudian ustadz/guru menyimak dan mengoreksi benar/tidaknya bacaan setoran tersebut selanjutnya dikirim atau disampaikan melalui via-rekaman juga. Kegiatan seperti ini hasilnya tentunya juga kurang, maka orang tua/wali murid harus menyimak anaknya dalam proses menghafal tersebut.

\section{3) Tidak tepat dengan jadwal pada buku pedoman tahfidz}


Jadwal merupakan salah satu manajemen perencanaan pembelajaran tahfidz untuk mencapai target hafalan. Pembelajaran homeschooling ini startnya kurang menentu, tetapi finisnya masih ditentukan yaitu pukul 21.00 WIB.

\section{4) Tidak bertatap muka dengan ustadz/guru}

Bertatap muka santri/siswa dengan adalah saling berhadap-hadapan antara guru/ustad dengan siswa/santri. Dengan demikian maka ustadz/guru dapat memperhatikan, menempatkan diri dan menciptakan pembelajaran tahfidz Al-Qur'an yang suasana yang mendukung, bertanggung jawab atas perkembangan dan pertumbuhan karakter dan kepribadian siswa/santri.

\section{5) Manajemen administrasi (absen siswa) bertumpu pada IT}

Informasi dan teknologi sangat dibutuhkan apalagi dengan adanya homeschooling akibat wabah Coronavirus (covid-19). Tetapi bagi santri/siswa yang kurang mengerti dengan IT bahkan tidak mempunyai android mereka tidak ikut dalam pembelajaran tahfidz atau tidak hadir/absen, sehingga mereka ketinggalan dari santri/siswa yang lain.

Atas dasar uraian di atas tentang kendala-kendala pembelajaran selama munculnya wabah/pandemic coronavirus (covid-19) yaitu sekolah diliburkan, setoran lewat via-rekaman, tidak tepat dengan jadwal pada buku pedoman tahfidz, Tidak bertatap muka dengan ustadz/guru, dan Manajemen administrasi (absen siswa) bertumpu pada IT. Selanjutnya dapat ditarik suatu simpulan bahwa problematika pembelajaran tahfidz AlQur'an di era wabah/pandemic coronavirus (covid-19) dapat berjalan dengan baik dengan berbagai penyelesaiannya.

\section{KESIMPULAN DAN SARAN}

Terlepas dari segala kelemahan dan kekekurangan penelitian ini, berikut ini peneliti menyampaikan beberapa saran untuk perkembangan dan keberhasilan dalam pelaksanaan pembelajaran tahfidz al-qur'an di SMP Islam Darul Muttaqin Metro Lampung, yaitu siswa/santri harus mendengarkan apa yang diucapkan oleh ustadz/guru, melaksanakan apa yang diperintahkan, mengamalkan apa yang didapatkan, dan mengajarkan apa yang bisa dari yang didapatkannya. Insyaaalah akan menjadi anak sholih, berbakti kepada kedua orang tua, memperjuangkan agama yang hak berguna bagi bangsa negara, masyarakat, dan lingkungannya. Sehingga dapat berfikir secara islamiah (qiyadah fikriyah) dan juga dapat mentadaburi ayat-ayat Al-Qur'an baik yang berkaitan dengan qobla' dunnya, ba'da dunnya, dan dunnya itu sendiri yang terdiri dari al-qauni, al-hayah, dan al-insan.

\section{DAFTAR PUSTAKA}

Arikunto,Suharsimi. (2002). PosedurPenelitian. Jakarta: RinekaCipta.

Burhanudin dkk. (2003).Manajemen Pendidikan. Malang : Universitas Negeri Malang

Emzir. (2015). Metodologi Penelitian Kuantitatif dan Kualitatif. Jakarta. PT Raja Grafindo Persada.

Hamalik, Oemar. (2008). Kurikulum dan Pembelajaran. Jakarta: PT. Bumi Aksara. 
Imron, Maisyaroh, Burhanuddin. (2003). Manajemen pendidikan, Analisis Subtantif, dan Aplikasinya dalam Institusi Pendidikan. Malang: Universitas Negeri Malang.

Karwono. (1993). Pemanfaatan Sumber Belajar Bidang Studi Ilmu Pengetahuan Sosial (IPS) Kelas V oleh Guru-Guru Sekolah Dasar di Kecamatan Blimbing Kotamadya Malang Jawa Timur. Tesis. IKIP Malang.

Lexy J. Moleong. Metodologi Penilaian Kualitatif. Bandung: Remaja Rosdakarya.

Lutfi, Ahmad. (2009). Pembelajaran Al-Qur'an dan Hadits. Jakarta: Direktorat Jenderal Pendidikan Islam.

Makbuloh, Deden. (2011). Manajemen Mutu Pendidikan Islam. Jakarta : PT Raja Grafindo Persada.

Makmun, Abin Syamsudin. (2010). Pengelolaan Pendidikan, Bandung: Pustaka Eduka.

Malayu,Hasibuan. (2007). Manajemen; Dasar, Pengertian, dan Masalah. Jakarta: PT Bumi Aksara.

Pimpinan Pusat Muhammadiyah. (2011). Himpunan PutusanTarjih. Yogyakarta: GRAMASURYA

Purwanto, Ngalim. (2000). Psikologi Pendidikan. Bandung: Remaja Rosda Karya.

Riduan, (2004). Metode Riset.Jakarta: Rineka Cipta.

Sagala, Syaiful. (2010). Konsep dan Makna Pembelajaran. Bandung: Alfabeta.

Saryono, (2010). Metodologi Penelitian Kualitatif. Jakarta: Nuha Media.

Shafiyyrrahman,Syaikh dkk. (2017). Shahih Tafsir Ibnu Katsir. Jakarta: Pustaka Ibnu Katsir.

Siauw, Felix Y. (2011). Muhammad Al-Fatih. Jakarta: AlFatih Press.

Sugiyono, (2005). Metode Penelitian Kuantitatif kualitatif dan R\&D. Bandung Alfabeta.

Sukardi, (2006). Penelitian Kualitatif-Naturalistik dalam Pendidikan. Yogjakarta: Usaha Keluarga Perum. UNY.

Suryobroto. (2009). Proses Belajar Mengajar di Sekolah. Jakarta: PT Rineka Cipta.

Tanzeh, Ahmad. (2009). Pengantar Metode Penelitian. Yogyakarta: Teras. 
Universitas Muhammadiyah Metro. (2016). Pedoman Penulisan Karya Ilmiah (PPKI). Metro: Program Pascasarjana.

Usman, Husaini. (2009). Manajemen Teori, Praktik, dan Riset Pendidikan. Yogyakarta : Bumi Aksara. 